\title{
Development of creative abilities of students using art technologies in the higher education
}

\author{
Oryngul S. Abilmazhinova, Kazakh Humanitarian Law Innovative University, Republic of Kazakhstan, \\ 071400, Semey, 11 Mangilik el str, Abai Kazakh National Pedagogical University, 050010, Almaty, Dostyk \\ ave., 13, Republic of Kazakhstan
}

Meiramgul Z. Janbubekova , Shakarim State University of Semey, Republic of Kazakhstan, 071412, Semey, Glinki Street, 20 «A»

Oxana G. Belenko, Shakarim State University of Semey, Republic of Kazakhstan, 071412, Semey, Glinki Street, 20 «A»

Sholpan Sh. Abisheva, Shakarim State University of Semey, Republic of Kazakhstan, 071412, Semey, Glinki Street, 20 «A»

*Gulzhaina K. Kassymova, Institute of Metallurgy and Ore Beneficiation, Satbayev University, 29/133, Shevchenko str., 050010, Almaty, Republic of Kazakhstan; Yogyakarta State University, l. Colombo Yogyakarta No.1, Karang Malang, Caturtunggal, Kec. Depok, Kabupaten Sleman, Daerah Istimewa Yogyakarta 55281, Indonesia; Abai Kazakh National Pedagogical University, 050010, Almaty, Dostyk ave., 13, Republic of Kazakhstan, g.kassymova@satbayev.university

\begin{abstract}
This article considers the features and specifics of the development of students' creative abilities using art technologies in the educational process of the university. At the moment, the most important condition for progressive development, both of each individual member of society and of the whole society, is the ability to creatively solve tasks. Moreover, the basic prerequisite for this approach is a properly organized pedagogical process of higher education for the development of the student's creative abilities at all stages of personal development. It was emphasized that the main emphasis in pedagogical practice should be placed on the development of the creative abilities of students of pedagogical specialties, since the multilateral potential of this profession largely determines those personal and socially significant achievements on which the personality of the current teacher is aimed. In the article, the authors consider and disclose the concepts of "creativity", "ability", "creative abilities" and "art technologies". The article also reveals the essence and content of art technology in high school and its role in the development of students' creative abilities. Skilled-experimental work on the development of creative abilities of students using art technologies was described. The research was attended by students of the faculty of "Humanities" of Shakarim State University of Semey. During the experiment, the program of purposeful activity was implemented to develop the creative abilities of students using art technologies. Analysis of the research results indicates that the use of art technologies in the teaching of the elective course "Development of students' creative abilities in the educational process of the university" has a positive impact on the development of the creative abilities of university students.
\end{abstract}

Keywords: education, creativity, ability, activity, student, art, technology.

Received: $13.11 .2020 \quad$ Accepted: 02.12.2020 $\quad$ Published: 07.01.2021

\section{INTRODUCTION}

At the present stage of the development of the higher education system, when the main task is to improve the quality of vocational training of graduates, ensuring their competitiveness in the labor market, the forefront is the problem of finding new approaches to the organization of the educational-educative process, which contribute to the creative self-development of the personality, the creative application of knowledge in specific situations, that is, finding their own individual, optimal way to solve various problems and issues (Cahapay, 2020).

The development of the creative abilities of future pedagogues-psychologists is one of the main tasks of higher professional education. The way to success of personality lies through a creative approach to work. At the same time, the creative approach is especially important in the profession of the pedagogue-psychologist (Gonzales, 2020). Advanced pedagogical science sees the main task of training not in the simple transfer to students of the certain amount of ready-made knowledge, but in the development of their creative independent thinking. 
Based on the biographies of outstanding scientists, inventors, painters and musicians, the famous researcher of the problem of creativity Luk (1973) identifies the following creative abilities.

1. The ability to see the problem where others don't see it.

2. The ability to curtail mental operations, replacing several concepts with one and using symbols that are increasingly capacious in informative relation.

3. The ability to apply skills acquired in solving one problem to solving another.

4. The ability to perceive reality as a whole without dividing it into parts.

5. The ability to easily associate distant concepts.

6. The ability of memory to provide the right information at the right time.

7. The ability to choose one of the alternatives of solving the problem before it is tested.

8. Ability to incorporate newly received information into existing knowledge systems.

9. The ability to see things as they are.

10. Easy to generate ideas.

The student must master the following techniques of creative thinking in the training process of higher education Kariev (2015):

- Not only watch, but also see - the ability to see the problem where for others everything was clear.

- Ability to curtail mental operations. In the process of thinking, a person makes the transition from one link in the chain of reasoning to another, because of this, he is not always possible to cover the whole picture, the whole phenomenon, to conduct reasoning from the first step to the last. The process of curtailing mental operations is the manifestation of the ability to replace several concepts with one related to a higher level of abstracting.

- Ability to transfer. The person in practical activities is associated with many phenomena. Important is the ability to apply the skills, acquired in solving one problem to solving another, that is, the ability to separate the specific aspect of the problem from the non-specific one transferred to other areas. This is, in fact, the ability to develop a generalizing strategy. Finding an analogy is a necessary condition for transferring the skill or idea.

- Integrity of perception. This means the ability to perceive reality as a whole, without this it is not possible to look at the problem from a new angle of view, to see a new one in the long-overdue.

- Readiness of memory. When the person seeks the solution to the problem, he can count not only on the information that he currently perceives, but also on the one that he will be able to extract from memory.

- Flexibility of thinking. It is ability to move quickly and easily from one class of phenomena to another, which is distant from the first in content. The lack of such flexibility is called inertia or stagnation of thinking.

- Ability to evaluate actions. The ability to evaluate and select one of many alternatives before testing is very important. Evaluative actions should be carried out not only after completion of the work, but also repeatedly during its course. Evaluative abilities are necessary for the future manager, who himself does not have time to work under the development, but must decide which of the options proposed by employees should be accepted.

- Ability to interlink. This ability to combine newly perceived information with what was previously known, the ability to group data in one way or another already in the process of perception as a condition for generating ideas.

- Ability to complete. This is the ability to bring work to the level where it acquires universal significance and social value.

If we consider abilities as qualities that open the way to creativity, then we need to remember that some proportion of creativity is present in any activity of the subject. The people that we call capable, talented and even brilliant are not endowed with some supernatural qualities that others do not have. They only vividly express the creative abilities inherent in one way or another to all people.

We believe that it is necessary to pay special attention to the development of the creative abilities of future pedagogues-psychologists in the process of professional training, since it is during this process that future pedagogues-psychologists get the possibility to apply and substantiate the acquired knowledge, abilities and skills, correlate their own system of values with the requirements and norms of the professional environment, consolidate and develop personal motivation for self-realization in real pedagogical activity.

It is important to use innovative technologies and teaching methods for developing the creative abilities of students in the pedagogical process of higher education. One of such innovative technologies is art technologies, which are methods, techniques, forms and means of various types of art used in the educational process in order to reveal and develop the creative potential of students. 
Art technologies (meaning - "art, craftsmanship") - are the new promising direction in modern education. They are based on a particular type of art (Svetonosova, 2020).

The application of art technologies in the educational process of the pedagogical university will allow:

1) to reveal the creative abilities and personal potential of future pedagogues-psychologists;

2) to develop the reflexive abilities of future pedagogues-psychologists;

3) to develop the competence to solve pedagogical tasks that may arise in vocational-pedagogical activities.

Types of art technologies include: audiovisual technologies (film criticism, video collage, video image creation), pictorial technologies (collage, spontaneous painting), theatrical-game technologies (improvisation, imitation, staging). In addition, art technologies can be implemented in various forms: creative workshop, rehearsal, cultural project, drama training. The main idea of art technologies is to use various types of art in the educational process with the purpose of creative self-development of students.

Thus, the use of art technologies in the pedagogical process of the university will contribute to the disclosure and development of the creative abilities of students, which will allow them to be creative in solving life problems.

The practical significance of this research is that the possibilities of art technologies in the pedagogical process of the university are shown, which are aimed at creating effective pedagogical conditions for the development of students' creative abilities, since in the student period the abilities and skills to be creative in completing tasks are most effectively formed and developed (Suparman \& Wijayanti, 2019).

\section{METHOD}

\section{Methods of development of creative abilities at students of university}

The analysis of the literature on the issue of use of art technologies in the pedagogical process of the university shows that the term "art technology" is formed on the basis of the combination of two separate concepts: "art" (meaning - art, handicraft) and "technology", the essence of which is to attract means of art to the educational process in order to develop and educate students through artistic and creative activity, as well as to solve various practical problems in a specific educational field. There is a synonymous concept - "Education through Art" in foreign scientific literature (EABPSE, 2005).

The concept of "art technology" is defined in different ways:

- artistic creativity associated with the action of three factors: expression, communication and symbolization (Bekker-Glosh \& Byulov, 1999);

- a set of means of art and methods of artistic-creative activity to achieve the intended pedagogical goal (Kungurova, 2013);

- the use of means of art to convey the feelings and other contents of a person's psyche in order to change the structure of his world perception (Liebmann, 2003);

- merging creativity and corrective practice as the method aimed at realizing hidden energy as a result of creative thinking, training, personal growth, as the influence on the motivational, emotional, adaptive sphere (Nikandrov, 1998);

- the ordered set of emotionally significant creative actions or interactions for students with the involvement of various types of art that ensure the achievement of the predictable result (Pospelova, Yu Yu \& Pronina, 2016);

- the methods, techniques, forms and means of different types of art applied in educational process for the purpose of disclosure and development of creative potential of the personality of students and awareness of the importance of the studied scientific facts, objects, the phenomena (Svetonosova, 2020);

- the important cultural-educational resource providing a new quality in the formation of professional competence of specialists. The potential is associated with the possibilities of increasing creativity, social mobility of the personality, communicative culture, readiness to projecting of social-pedagogical situations, motivation for its self-realization in professional activity and social creativity, the formation of the active life position (Starikova, 2008);

- training provided by means of artistic creativity (Shkil, 2011).

Along with art technologies, we used interactive educational technologies in the pedagogical process of the university. They provide for the process of training that allows, on the basis of active interaction between the teacher and students in the training process, to create favorable conditions for the harmonious development of the personality (Kariyev, 2018). 
Thus, the development of students' creative abilities using art technologies in the pedagogical process of the university will contribute to the disclosure of students' creative abilities, creative rethinking of professional pedagogical activities, self-development and, most importantly, the increase in the level of pedagogical culture.

The analysis of scientific, special literature and the generalization of experience in the application of art technologies make it possible to conclude that their integrated use in the higher education system will be able to "discover" new knowledge, develop creativity, analyze their behavior and activities, develop reflexive abilities, which are certainly necessary for the future pedagogical profession.

We carried out the following types of work for the implementation of the tasks of research: studying and summarizing previously conducted researches on the problem of developing the creative abilities of students; analysis of the works of scientists investigating the issues of use of art technologies at the university.

\section{RESULTS}

\section{Theoretical understanding of the concepts of "creativity," "ability" and "creative abilities".}

It is necessary to disclose the concepts of "creativity", "ability" and "creative abilities" in order to solve the set tasks of the research.

In philosophy, creativity is considered as the process of human activity that creates qualitatively new material and spiritual values. Based on this methodological position, many researchers define creativity as the human activity that creates new material and spiritual values, which have the social significance.

Creativity is identified with creative activity in the works of psychologists of Ananyev (1962), Bogoyavlenskaya (2002), Vygotsky (1997), Leontiev (1983), Rubinstein (1989). So, Vygotsky has the statement that creativity is "... such activity that creates something new, anyway, whether will it be the creation by creative activity of some of thing of the outside world or the known construction of mind or feeling, living and discovering in man himself" (Vygotsky, 1997; p. 3).

According to psychologists, human activity by its very essence is creativity, as a result of which the person finds something new, unknown.

Despite the existing differences in the disclosure of the essence of the concept of "creativity", we can trace the certain commonality in the views of researchers regarding the indicators of the process of creating the new one that promotes to the development of personality.

In pedagogy, this concept is defined as follows: "Creativity is the activity of the person to create the qualitatively new, deliberately perceived by him as generated by an internal desire for self-realization or an objective need of the person; activity, considered both at the subjective and objective level (depending on the nature of creativity), according to the criterion of recognition of novelty" (Popov \& Kruglov, 2011; p. 52]. There is such definition of this concept as well: "the content of creativity will be considered the solution of non-standard tasks in any sphere of activity (Tsvetkov, 2009; p. 8).

It is necessary to disclose the concept of "abilities" at the consideration of the concept of "creative abilities". It is quite often spoken about the problem of the development of creative abilities in the pedagogical and psychological literature. It should be noted that abilities relate to the most significant mental properties of an individual. Most researchers, investigating the problem of abilities, correlate abilities and skills in the certain type of activity, and that the concept of "ability" comes from the characteristic of the person who performs this activity.

Many domestic psychologists were engaged in the research of abilities. Among them, it can be distinguished the works of Ananyev (2016), Vygotsky (1999), Zharikbaev (1968), Namazbayeva (2014), Leontyev (1983), Petrovsky \& Yaroshevsky (2000), Rubinshtein (1989), Teplov (1985). We decided to prepare the content-analysis of the concept of "abilities" (Table 1).

Table 1. Content-analysis of the concept of "abilities"

\begin{tabular}{|c|l|}
\hline Author & Definition \\
\hline Ananyev (2016) & $\begin{array}{l}\text { The manifestation of the creative development of the mind, but not the } \\
\text { simple accumulation of knowledge, therefore, the manifestation of the } \\
\text { creative application of this knowledge, the author's position of the person } \\
\text { himself regarding knowledge, which he assimilates independently and } \\
\text { consciously. Thus, it is assumed that ability is not the simple } \\
\text { accumulation of knowledge }\end{array}$ \\
\hline
\end{tabular}




\begin{tabular}{|l|l|}
\hline Kalashnikov (2014) & $\begin{array}{l}\text { individual psychological characteristics of the person, manifested in } \\
\text { activity and being the condition of success in its implementation }\end{array}$ \\
\hline $\begin{array}{l}\text { Petrovsky \& Yaroshevsky } \\
(2000)\end{array}$ & $\begin{array}{l}\text { such psychological peculiarities of the person which predetermine the } \\
\text { success of acquisition of knowledge, abilities, skills, but which are not } \\
\text { limited to the presence of this knowledge, skills }\end{array}$ \\
\hline Rubinshtein (1989) & $\begin{array}{l}\text { complex synthetic formation, which includes a range of data without } \\
\text { which the person would not be capable of any particular activity, and } \\
\text { properties that are developed only in the process by the certain way of } \\
\text { organized activity }\end{array}$ \\
\hline Teplov (1985) & $\begin{array}{l}\text { abilities cannot exist except in the continuous process of development. } \\
\text { ability that does not develop, which is lost over time in practice by the } \\
\text { person when he does not use it }\end{array}$ \\
\hline
\end{tabular}

These definitions allows to draw the conclusion that any ability is the ability to some activity and includes the necessary properties and qualities that meet the requirements of this activity.

The works of Abdigapbarova (1998), Berkenova (2015), Kenzhebayeva (2014), Nebesaeva (2016) are devoted to the problem of creative abilities, which say that creative abilities can be developed; and in the process of mastering knowledge about the ways of research activity and the abilities of its implementation there is the development of the personality in the direction of its preparation for activity at the level of creativity.

According to Vygotsky (1999) creative abilities are human properties, which in the process of activity, based on the reorganization of existing experience and the formation of new combination knowledge, generate something new.

Bolshakova (2001) defines creative abilities as the complex personal quality that reflects ability of the person to creativity in various spheres of vital activity, and also allows to support other people in creative self-realization. This is a high degree of enthusiasm, intellectual activity, and cognitive amateur activity of the personality.

Motkov (1993) by creative abilities understood the ability to be surprised and cognize, the ability to find solutions in non-standard situations, this is the focus on discovering the new one and the ability to deep perception of own experience. Recent research states that students can be creative when they are engaged in problem-based learning styles and online education system has a potential to create an appropriate atmosphere for personal development if used properly (Kassymova et al., 2020; Arlinwibowo, 2020; Kassymova, 2019).

Creative abilities, according to Postalyuk (1989), include:

1) abilities to see the problem as the most important quality that determines the systemacy of the practical-cognitive process;

2) the originality of thinking, revealing in the ability to look at an object in the non-traditional way, to see it in the new light;

3) dialectical thinking as the most important integral characteristic of the creative style of activity;

4) ease of association as the ability to create new psychological formations;

5) ease of integration of ideas or ability to generate ideas;

6) the ability to evaluative actions and criticality of thinking, considered as a strictly controlled attitude to incoming information;

7) the ability to wide transfer of knowledge (Postalyuk, 1989; p. 77].

Both personal and social factors contribute to the development of creative abilities, which in the educational process are transformed into pedagogical factors, primarily associated with the organization of educational activities of students.

Successful organization of the procedural side of creativity, according to Newell (1965), Shaw (1965), Simon (1965), is possible if:

- the product of mental activity has novelty and value;

- the mental process is also differ by novelty in the sense that it requires transformation or rejection of previously accepted ideas;

- the mental process is characterized by the presence of strong motivation and stability, taking place during a significant period of time (constantly or intermittently), or with great intensity;

- the problem, posed initially, is vague and poorly defined, so that its reformulation is required (Newell, 1965). 
Consequently, the implementation of activities in the new conditions requires new approaches to the performed subject actions, finding new ways. From the foregoing, we can conclude that if certain conditions are created, students can be involved in active creative activity.

\section{Primary diagnostics of the level of formation of creative abilities at students of the university}

Measuring the level of formation of creative abilities of university students was carried out on the basis of the Shakarim State University of Semey at the faculty of Humanities. Students of the second and third years of training of the specialty "Pedagogy and Psychology" took part, 162 respondents were in total. We formed an experimental group of 79 students, 83 students were included in the control group. At the beginning of the experiment, we conducted the primary diagnostics of the level of formation of students' creative abilities. During the primary diagnostics, there was used the questionnaire of creativity of Johnson (1979), consisting of characteristics of creative thinking and behavior. The obtained data are presented in Table 2.

Table 2. Results of primary diagnostics of manifestations of creativity (according to Johnson)

\begin{tabular}{|l|l|l|l|l|}
\hline \multirow{2}{*}{ Creativity level } & \multicolumn{2}{|l|}{ Experimental group } & Control group \\
\cline { 2 - 5 } & Number of persons & $\%$ & Number of persons & $\%$ \\
\hline Very low & 7 & 8,8 & 9 & 10,8 \\
\hline Low & 32 & 40,5 & 35 & 42,1 \\
\hline Average & 27 & 34,1 & 26 & 31,3 \\
\hline High & 9 & 11,3 & 8 & 9,6 \\
\hline Very high & 4 & 5,06 & 5 & 6,02 \\
\hline
\end{tabular}

According to the results of the primary diagnostics, there were not found significant differences between the parameters of personal creativity and creative manifestations of the personality of the control and experimental groups. In general, the subjects of both groups can be described as having a low average score on the parameters of personal creativity (curiosity, imagination, risk, complexity). According to the results of Johnson's method, average results in both groups are characterized by low and average levels of creative manifestations of personality for most subjects. It should be noted that low results of test do not indicate a lack of creativity in some subjects, since creative manifestations are spontaneous and they are not subjected to arbitrary regulation, which takes into account the used diagnostic method intended to actually determine creative personalities in the particular selection at the time of testing.

Thus, we can talk about the homogeneity of groups on the development of parameters and manifestations of personal creativity. The used methods made it possible to obtain general data on personal creativity and creative manifestations of the personality that allows to give the general characteristic of the level of development of the creative abilities of the subjects.

\section{Program of targeted activity on the development of creative abilities of students using art technologies in the pedagogical process of the university.}

In accordance with the purposes and tasks of the research, there was organized the formative experiment to develop the creative abilities of students using art technologies, which ensured the creation and observance of psychological-pedagogical conditions for the development of the creative abilities of students. Realization of the experiment was carried out among students of the experimental group, which included students of 3 year training of the specialty "Pedagogy and Psychology". Work on the development of students' creative abilities using art technologies in the pedagogical process of the university was carried out during the 2018-2019 academic year.

The purpose of the formative experiment is to create favorable conditions for the development of students' creative abilities, as well as their creative activities in the process of professional training.

The program of the formative experiment provides for the introduction of the special elective course "Development of students' creative abilities in the educational process of the university", during the implementation of which art technologies were used.

The purpose of the elective course is the development of the creative personality, which is able to plan and comprehend own activity, find non-standard solutions of problems, energetically engage in creative activity and aspire to self-improvement.

As part of the study of this elective course, the following topics were studied: 
1. Psychological-pedagogical analysis of the problem of development of creative abilities of students.

2. Formation of motivation as the condition for the development of students' creative potential.

3. Creative potential of personality and peculiarities of development of creative abilities of students in educational process of university.

4. Modeling of the system of development of creative abilities of students in the process of educational-professional activity.

5. Psychological-pedagogical conditions of students' creative development.

6. Peculiarities of the application of art technologies for the development of student creativity.

7. Organization of independent work of students in the university for development of creative abilities of personality.

The basis of the training is the practical activity of students on the study of this course. When organizing classes, the following requirements were observed:

- ensuring the realistic collision with the problem, immersion in it before its formulation, collision of opposite concepts, images, ideas throughout the lesson;

- interaction of intellectual, strong-willed, emotional spheres in the process of creativity among all participants of the process;

- use of techniques that allow to connect the process of thinking with practical actions, use the psychophysical apparatus of students, stimulate unconscious components of the creative process;

- connecting reflexive mechanisms at the end of each stage of the lesson;

- bringing any idea to completion, completing any started action.

Art technologies were used in each lesson. For example, when studying the topic "Modeling the system of development of students' creative abilities in the process of educational-professional activities", it was used one of the methods of art technologies "Journal photo collage technique". The essence of the method is that the journal material, chosen by the participants, is able to identify topics and problems that remain undisclosed during the oral discussion. Students independently select material from journals and other printed products and, using separate fragments of text, form the composition on the sheet of paper, give it a name, thus denoting the solution to the declared problems. The process and results of the work are discussed at the end of the work.

One of the effective methods of art technology is the "Business theater". According to this method, students theatricalize the behavior of the person in the certain environment. At the same time, the participant mobilizes all his experience, knowledge, skills, he must get into character of that or those person, understand his actions, evaluate the situation and choose the right behavior strategy. The purpose of the staging method is to improve the ability to navigate real circumstances, objectively evaluate own behavior, take into account the needs and capabilities of another personality, establish contact with it, influence interests and activities, without using the formal attributes of power, orders.

A fairly close method is psychodrama. This is the social-psychological theater that contributes to the development of the ability to feel the situation in the team, analyze the state of the partner and the ability to establish productive contact with him.

Modeled professional relationships during the business game involve the student in the simulated professional environment, contributing to intensive professional development. Interactions in the game have the emotional-creative search character, contribute to the disclosure of the personal potential of the student.

Use of art technologies during the classes creates conditions for realization of the high potential of students in assimilation of scientific knowledge and for their general emotional development. Here, students can realize their individuality, their own uniqueness, reach the new level of self-awareness, and increase their self-rating. So, art technologies form the professional qualities of the future pedagoguepsychologist in conditions close to real ones.

\section{DISCUSSION}

After conducting the formative experiment on the development of students' creative abilities using art technologies, we organized the re-measurement of the level of formation of creative abilities of university students' in the control and experimental group. As it was previously stated, there was introduced in the experimental group the program of targeted activity on the development of students' creative abilities using art technologies within the framework of which the elective course "Development of students' 
creative abilities in the educational process of the university" was implemented. During the same period in the control group, training was carried out as usual.

At the final stage of the research (after conducting the formative experiment), the final diagnostics of the level of formation of the creative abilities at the university students in the control and experimental group was carried out. The comparative characteristics of the manifestations of creativity, presented in Table 3, made it possible to draw the following conclusions.

Table 3. Comparative characteristics of manifestations of creativity (according to D. Johnson)

\begin{tabular}{|c|c|c|c|c|c|c|c|c|}
\hline \multirow{3}{*}{$\begin{array}{l}\text { Creativity } \\
\text { level }\end{array}$} & \multicolumn{4}{|l|}{ Before } & \multicolumn{4}{|l|}{ After } \\
\hline & \multicolumn{2}{|c|}{ Experimental group } & \multicolumn{2}{|c|}{ Control group } & \multicolumn{2}{|c|}{ Experimental group } & \multicolumn{2}{|c|}{ Control group } \\
\hline & $\begin{array}{l}\text { Number of } \\
\text { persons }\end{array}$ & $\%$ & $\begin{array}{l}\text { Number of } \\
\text { persons }\end{array}$ & $\%$ & $\begin{array}{l}\text { Number of } \\
\text { persons }\end{array}$ & $\%$ & $\begin{array}{l}\text { Number } \\
\text { of } \\
\text { persons }\end{array}$ & $\%$ \\
\hline Very low & 7 & 8,8 & 9 & 10,8 & 3 & 3,8 & 7 & 8,4 \\
\hline Low & 32 & 40,5 & 35 & 42,1 & 15 & 18,9 & 30 & 36,1 \\
\hline Average & 27 & 34,1 & 26 & $\begin{array}{l}31, \\
3 \\
\end{array}$ & 34 & 43,03 & 28 & 33,7 \\
\hline High & 9 & 11,3 & 8 & 9,6 & 22 & 27,8 & 12 & 14,4 \\
\hline Very high & 4 & 5,06 & 5 & $\begin{array}{l}6, \\
02\end{array}$ & 5 & 6,3 & 6 & 7,2 \\
\hline
\end{tabular}

Analysis of the results of diagnostics in the experimental group according to Johnson's method allowed to reveal significant differences in the following levels. The number of students with the average and high level of creativity increased (at $\mathrm{p}<<0.05$ ), and the number of subjects with the low level of creativity decreased (at $p<0.001$ ). Significant differences in the experimental group occurred by increasing the number of subjects with average and high level, which we do not observe in the control group. These significant differences can be explained precisely by the result of the impact of the program of targeted activity to develop the creative abilities of students using art technologies.

The specified changes of the manifestations of creativity at the subjects of the experimental group indirectly indicate the effectiveness of the program of targeted activity on the development of students' creative abilities using art technologies. Significant differences of the results of the final diagnostics in the experimental and control groups were found only by the average (at $p<0.05)$ and low $(p<0.001)$ level of manifestations of creativity, which is significantly higher at students of the experimental group. We do not observe significant differences on the very high level of manifestations of creativity in the experimental group, which can be explained as follows.

The suggested program of targeted activity on the development of creative abilities of students using art technologies is mainly aimed at actualization of the existing creative potential of students, as evidenced by the decrease in the number of subjects with the low level of creativity and the increase in the number of subjects with the medium and high level. This fact is explained by the fact that the very high level of development of creative manifestations is probably due to biological factors, so it is less sensitive to psychological-pedagogical influences. The presence of the very high level of manifestation of creativity implies the modification of the developed program, as well as the use of psychological means that have the large individual directivity.

Thus, positive changes are explained by the peculiarity of the implemented program, which assumes involving students in creative activity, and the presence of the individual approach to students, the main purpose of which is to reveal creative potential and relieve psychological tension and discomfort that impedes the feeling of self-confidence.

\section{CONCLUSION}

The analysis of the obtained results allows to argue that training with use of art technologies qualitatively exceeds classical education. It consists in the fact that the student actively and creatively thinks, looks for expedient ways out of various pedagogical situations, trains thinking, memory, attention, imagination, makes non-standard decisions that bring great productive results.

In order to assess the level of development of creative abilities, it is advisable to use not only standardized diagnostic materials, but also specially developed tasks that take into account the specifics of the certain sphere of creative activity and allow to analyze the dynamics of the level of development of special creative abilities. 
The creative pedagogue-psychologist is the creative person who actualizes and develops own creative potential. The creative abilities of the pedagogue-psychologist are the synthesis of the properties and traits of the person character, which characterize the degree of their compliance with the requirements of the certain type of educational-creative activity and determine the level of effectiveness of this activity. The results of the conducted research showed that one of the ways to develop the creative personality of the future pedagogue-psychologist in the process of training at the university is the use of art technologies.

Summarizing the obtained results, we can say that the developed program is effective, which means that it creates the conditions for actualization of the creative potential of the student's personality and developing his creative abilities. Art technologies allow students to realize their own personal and professional possibilities, develop creative abilities to the high level, meet the needs in novelty and nonstandard ways to solve professional problems.

\section{REFERENCES}

Ananyev, B. G. (1962). On the ratio of abilities and giftedness//Problems of abilities.

Arlinwibowo J., Retnawati H., Kartowagiran B., \& Kassymova G. K. (2020). Distance learning policy in Indonesia for facing pandemic COVID-19: School reaction and lesson plans. Journal of Theoretical and Applied Information. Volume 98, Issue 14, 31 July 2020, Pages 2828-2838.

Abdigapbarova, U. M. (1988). Preparing students for the use of Kazakh national ornamental art in educating students: abstract of the dissertation of the Candidate of Pedagogical Sciences. Almaty, 20.

Bekker-Glosh V., \& Byulov E. (1999). Art therapy at the Alixeaner Psychiatric Hospital of Münster//Healing art. No. 1. Page 42-58.

Berkenova G. (2015). Development of the creative abilities of the personality in the theory and practice of training//International Scientific and Practical Conference "Competent Graduate of the New Time". - Donetsk.-p. 28-34.

Bogoyavlenskaya, D. B. (2002). Psychology of creative abilities: training manual for students of the universities. - M.: Publishing Center "Academy".

Bolshakova, L. A. (2001). Development of creativity of the primary schoolchild. Journal "Director of studies of primary school". No. 2,

Cahapay, M. B. (2020). An internal evaluation of higher education curriculum using data transformation model. Asian Journal of Assessment in Teaching and Learning, 10(2), 1-9. https://doi.org/10.37134/ajatel.vol10.2.1.2020.

Education though art. Building Partnerships for Secondary Education (EABPSE). Unesco expert panel meeting. Newark Museum, (2005, October 27). Secondary Education in the 21st Century/Internetresource: unesdoc.unesco.org>images/0014/001442/144239e.pdf

Gonzales, N. A. P. (2020). 21st Century Skills in Higher Education: Teaching and Learning at Ifugao State University, Philippines. Asian Journal of Assessment in Teaching and Learning, 10(2), 72-81. https://doi.org/10.37134/ajatel.vol10.2.8.2020.

Johnson, D. L. (1979). Creativity checklist (Cch) Cat. No 33780.

Kalashnikov, M. M. (2014). To the question of the essence of the concept of abilities in pedagogy and psychology//Bulletin of Belarusian State University. No. 1. - Page 5-15

Kariyev, A. D. (2018). A study of teacher's readiness for teaching students by methods of interactive learning as a condition for developing students' creative abilities/A.D. Kariyev, A.T. Selkebayeva, G.K. Bespayeva, B.I. Baigundinova, A.G. Kabdualieva//RevistaEspacios, Vol. 39 (№ 21), Page 15 Internet resource: http://www.revistaespacios.com/a18v39n21/18392115.html.

Kariev, A. D. (2015). Model of readinessof the teacher to formation on the basis of interactive methods as a condition of development of creative abilities of students/A.D. Kariev//Bulletin of Priamur State University named after Sholom-Aleikhem, Birobidzhan. - 2015, No. 1 (18), p.66-71.

Kassymova G., Akhmetova A., Baibekova M., Kalniyazova A., Mazhinov B., \& Mussina S. (2020). E-Learning Environments and Problem-Based Learning. International Journal of Advanced Science and $\begin{array}{llllll}\text { Technology, } & 29(7 \mathrm{~s}), & 346 & 356 . & \text { Retrieved }\end{array}$ http://sersc.org/journals/index.php/IJAST/article/view/9447

Kassymova G. K., Duisenbayeva Sh. S., Adilbayeva U. B., Khalenova A.R., Kosherbayeva A. N., Triyono M. B., \& Sangilbayev O. S. (2019). Cognitive Competence Based on the E-Learning. International Journal of Advanced Science and Technology, 28(18), 167 - $177 . \quad$ Retrieved from http://sersc.org/journals/index.php/IJAST/article/view/2298 
Kenzhebayeva, T. V. (2014). Future Teachers Intellectual and Creative Potential Development / B.Zh.Turganbayeva, R.Zh. Mukhmetova, A.D. Kariyev, Zh.S. Baisalbayeva, // Life Science Journal;11(1): 321-324 (ISSN:1097-8135). http://www.lifesciencesite.com.49

Kungurova, I. M. (2013). Art-technologies in teaching the discipline "Technologies and methods of foreign language teaching" at the university//Bulletin of the Ishim State Pedagogical Institute named after P.P. Ershov. Vol 5(11). Page 46-51.

Leontiev, A. N. (1983). Activity, consciousness, personality/A.N. Leontiev//Selected psychological works, in 2volumes. - M.: Pedagogy, V.2. - p. 318.

Liebmann, M. (2003). Art Therapy for Groups: a handbook of themes, games and exercises. Cambridge Boston - L.: SHAMBALA, 2003. P. 40-46.

Luk, A. N. (1975). Learn to think. - M., Knowledge.

Motkov, O. I. (1993). Psychology of self-knowledge of personality. Practical manual. M., "Triangle".

Namazbaeva, Zh. I. (2014). History, state and trends of modern psychology: Training manual. Almaty,152.

Nebesaeva, Zh. O. (2016). Using the means of art-pedagogy in the visual arts // Bulletin of Abai Kazakh National Pedagogical University. - Series "Young scientist. Searches. Problems". - No. 2 (8). Almaty, -P. 41-44.

Newell, A. (1965). Processes of creative thinking/ A. Newell, D.S. Shaw, G.A. Simon// Psychology of thinking: Collection / Translated from German into English. - M.: Progress, 1965. - P. 500-530.

Nikandrov, N. D. (1998). Spiritual values and human education// Pedagogy. - No. 4. p. 3-8.

Petrovsky, A. V., \& Yaroshevsky, M. G. (2000). Psychology: textbook for universities/A.V. Petrovsky, M.G. Yaroshevsky//- M.: Publishing Center "Academy".

Pospelova, Yu.Yu., \& Pronina. N. S. (2016). Art technology as a means of forming the professional competencies of the foreign language teacher//Problems of modern pedagogical education. No. 522. Page 189-196.

Popov V. V., \& Kruglov, Y. G. M. (2011). Creative pedagogy. Methodology, theory, practice.

Postalyuk, N. Yu. (1989). Creative style of activity: pedagogical aspect/N.Yu. Postalyuk. - Kazan: Publishing House of Kazan University, 1989. - 206.

Rubinshtein, S.L. Fundamentals of general psychology: in 2 vol./S.L. Rubinshtein//- M.,1989, V. I. - 488 p., V. 2. -328.

Starikova, S. V. (2008). Art technologies as a means of preparing students for social-pedagogical activity in the system of professional education//Siberian pedagogical journal. No. 8. Page 415-425.

Shkil, I. E. (2011). Analysis of the application of art technologies as a means of developing the communicative competence of IT-specialists//Topical problems of the humanities and natural sciences. No. 12. Page 231-234.

Suparman, S., \& Wijayanti, D. D. (2019). Design of realistic mathematics-based student worksheets to improve students' critical thinking ability. Asian Journal of Assessment in Teaching and Learning, 9(1), 38-43. https://doi.org/10.37134/ajatel.vol9.no1.4.2019.

Svetonosova, L. G. (2020). Art technologies as a means of forming the pedagogical culture of the future teacher//World of science. Pedagogy and psychology. 2016. No. 3. URL: https://cyberleninka.ru/article/n/art-tehnologii-kak-sredstvo-formirovaniya-pedagogicheskoykultury-buduschego-uchitelya (Date of access: 14.05.2020).

Teplov, B. M. (1985). Selected works: in 2 volumes/B.M. Teplov//- M: Pedagogy.

Tsvetkov A.N., Zarembo V.E. Methods of solving creative problems in management: training manual.

Vygotsky, L. S. (1999). Pedagogical psychology/L.S. Vygotsky. - M.: Pedagogy-press.

Vygotsky, L. S. (1997). Imagination and creativity in childhood/ L.S. Vygotsky. - St. Petersburg: Union.

Zharikbaev, K. B. (1968). Development of psychological thought in Kazakhstan (from the second half of the XIX century to the present day). - Alma-Ata: Kazakhstan. 